\title{
Are Good Readers Good Writers?
}

\author{
Lahcen Belmekki
}

\author{
Language and Society Laboratory, Ibn Tofail University, Kenitra, Morocco
}

\begin{abstract}
This paper raises the questions whether good readers are good writers. Regarding the importance of reading and writing as basic literacy skills, a lot of research has been carried out in order to make learning these skills easy and successful. Being able to use English in a globalized world can not only enable users of English to compete locally or nationally, but also to seek better opportunities within the international community. Although research has recognized the need for developing effective reading and writing skills, researchers affirm that language learners, especially ESL and EFL, still face different difficulties in reading or writing.Hence, this study investigates the relation between reading and writing among high school EFL learners in Morocco. A correlation test has been used to compare the performance of high school students in both the reading and writing tests. The results of this comparison are used to test the research hypothesis, which hypothesizes that there is no significant difference between the participants reading and wring abilities. The findings of this study support other studies which highlight the strong link between the learners' abilities to write and read in English. The results strongly suggest that reading and writing be integrated in Moroccan classes (both in the teaching and learning process; at the level of classroom activities and tasks, textbooks, syllabus, testing, and training). Future research, based on the limitations of the current study and on the gaps in literature, should be directed towards a deep analysis of the interactive nature between reading and writing so as to put forward practical tips for successful integrative language teaching and learning.
\end{abstract}

Keywords-learning and teaching, reading, writing, integrating, correlation.

\section{INTRODUCTION}

Writing and reading are assumed to be among the most basic skills that learners should develop since these skills are essential for their success (M.E.N, 2009). According to Billy (2010), the world has become a global village undergoing re-ordering, and any country whose citizens cannot read and write well in a universal language (English being an international language) may not compete well. Countries like Morocco have emphasized the importance of developing their citizens' literacy skills. For instance, in 1991 Sadiqi, like other Moroccan scholars, did not only highlight the importance and value of learning English in Morocco, but also referred to the point that the spread of this language is not restricted to the educational context.

As for reading, Julian Hermida (2009) states that "In the past decades researchers discovered a mutual relationship between a student's academic reading skills and academic success" (p. 20). Thus, success at the university level mainly depends on existing pre-entry college attributes, including the mastery of some fundamental academic skills (Tinto, 1993, cited in Hermida, 2009).Olson and Land (2007) argues that linking reading to writing can facilitate learning. Another argument for this study is that quite a number of commentators and researchers have complained that all categories of learners of English as a Second Language (ESL) displayed difficulty in learning to read and write (Billy, 2010). Such difficulties are not restricted to ESL learners, EFL ones are not an exception. Many teachers believe that some of the difficulties students face in writing can be related to their reading abilities. They argue that many students do not write well because they do not read or have not developed certain effective reading skills.

The development of students writing skills has been at the center of research for a long time. Different attempts have been introduced to help students develop their writing skills. Some of these suggestions are related to pedagogical matters, others are related to learners. Krashan, for instance, (as cited in Al-Saadat,2004) argues that "second language learners' writing competence derives from large amounts of self motivated reading for interest and/or pleasure"(p. 217).Zamel (as cited in Abdullah Ibrahim Al-Saadat, 2004) also states that "writing is what makes it possible for us to read."This suggests that there is a significant correlation between the development second language learners reading and writing abilities. Hence, this paper attempts to promote the teaching and development of the writing skill through examining its relation to reading in the EFL context.

Through investigating the correlation between reading and writing, the findings of the current study can be useful at different levels. These findings can be beneficial to learners, teachers, textbook writers, syllabus designers, education policy makers, and researchers. 


\section{LITERATURE REVIEW}

This section provides a review of previous research on the correlation between reading and writing. Krashen is one of the researchers who advocate the strong relation between reading and writing. He also claims that second language learners' writing competence derives from amounts of reading for pleasure (Al Saadat, 2004). Krashen (ibid) also reported the results of research done by Kimberling, Wingate, Rosser, DiChara and Krashen.

They examined this issue directly. They found very clear differences between good writers and poor writers - good writers reported more pleasure reading at all ages, and especially during high school years. However, not one poor writer reported "a lot" of pleasure reading during high school. Smith (1982) describes reading as a process that involves both the extraction and supplying of information. (Krashen as cited in Al Saadat, 2004, p. 21)

Carson et al., (1990) examines whether or not reading and writing relationship are closely related in first and second language contexts. Their results suggest that the interaction between reading and writing is complex. A lot of studies on first language have also identified common cognitive processes and/or structural components underlying reading and writing abilities. Such studies maintain that improvement and instruction in one skill can enhance capabilities in the other (Al-Sadat, 2004). The reviewed literature indicates that research on the relation between reading and writing in L2 context is still limited. Another conclusion is that empirical studies, which is lacking in the EFL context, could enhance our practical understanding of the benefits and effectiveness of the integrated reading and writing instruction (Cho \& Griffer, 2015). Consequently, the current empirical study aims to contribute to the development of research on integrated reading and writing instruction in the EFL context.

The primary concern of this study is to examine the relation between reading and writing. It focuses on the development of the reading and writing skills among EFL learners. It aims at investigating whether the development of these skills is interrelated. Another concern of this paper is to examine whether the degree of correlation varies across levels.

In order to achieve the above-mentioned aims, the following questions must be raised:

$>$ Is there a significant correlation between students' performance in the reading and writing tests?

$>$ Does correlation between students reading and writing abilities among EFL learners vary across levels?

This study aims at studying the relation between reading and writing. The research hypothesis of this paper can be stated as null: There is no correlation between reading and writing. It is expected that there will be no significant difference in the students' results in the reading as well as the writing tests. It is also assumed that correlation significance does not vary through levels.

In order to examine this correlation, the data of this paper are the scores obtained in the reading and writing tests. These tests are the research instruments used in this study. The reading test targets students reading skills while the writing one tests students writing abilities. Correlation coefficient, the most appropriate statistical procedure in this case, is used to test the research hypothesis and to verify the correlation between reading and writing. Concerning the informants of the study, they are high school students.

\section{METHODS}

\section{Participants in the study}

The informants of the study are high school students. They have been learning English for two or three years. They are from more or less the same educational background. The following table provides some demographic information about the participants in the study.

Table.1: Demographic information about the participants

\begin{tabular}{|l|l|l|}
\hline $\begin{array}{l}\text { Total number of } \\
\text { participants }\end{array}$ & 120 & 60 \\
\hline \multirow{2}{*}{ Level } & Common core & 60 \\
\cline { 2 - 3 } & $\begin{array}{l}\text { First year } \\
\text { baccalaureate }\end{array}$ & 60 \\
\hline \multirow{2}{*}{ Major } & humanities & 60 \\
\cline { 2 - 3 } & science & 51 \\
\hline Gender & males & 69 \\
\cline { 2 - 3 } & females & \\
\hline Age & Between 16 and 18 & \\
\hline
\end{tabular}

\section{Data collection method}

Reading and writing tests are used to collect data to test the research hypotheses and to answer the research questions. Two reading and two writing tests were used: a reading and a writing test for common core students and another reading and writing test for first year baccalaureate students. These tests were introduced in the end of the first semester of the academic year 2015/2016. They were part of the final test introduced at the end of the semester. It has to be noted that the participants were given different tests based on their level. Although these tests vary in the degree of difficulty, they include the same test items. The reading tests assess the learners' ability to use some basic reading skills such as:

$>$ Reading for the main idea 
$>$ Reading for details

$>$ Inferring word meaning from context

$>$ recognize and identify reference

Concerning the writing test, the following abilities are targeted:

- Generating relevant and appropriate ideas related to the topic given

- Relevance and organization of ideas

- Correct and appropriate use of the different mechanics of writing (spelling, grammar, punctuation, capitalization)

- Word order

For research validity purposes, the students' papers were corrected by the teacher who is the researcher at the same time. As for the writing test, a detailed scoring checklist was used to make the correction process less subjective. It has to be noted that this checklist is an adaptation of the correction checklist used in the national baccalaureate exam correction specifications.

\section{Hypotheses testing}

This paper is based on two main null hypotheses. The first hypothesis is related to the correlation between the development of high school learners reading and writing skills while the second one is about whether this correlation varies through levels. In order to test the first research hypothesis, a comparison of the performance of all the participants is done (both common core and first year baccalaureate students). Testing the second research hypothesis is done through comparing the performance of the participants based on their level: common core students' performance in the reading and writing tests was considered first and then first year baccalaureate students. The purpose of these comparisons is to examine whether the degree of correlation varies from one level to another.

\section{RESULTS}

This section presents the results of the study. This paper is about the correlation between reading and writing skills development among high school students. This study is based on two hypotheses. Thus, two comparisons are made. Using Pearson correlation test, the results of these comparisons are presented tables 2 and 3 .

Table 2 presents the results of the comparison between students' (all the participants) performance in the reading comprehension test and that of writing.

Table.2: Correlation between reading and writing among both common core and first year baccalaureate students

\begin{tabular}{|r|r|r|r|}
\hline R value obtained & $\begin{array}{r}\text { Critical value } \\
\text { needed }\end{array}$ & DF & $\begin{array}{r}\mathrm{P} \\
.05\end{array}$ \\
\hline 0,4964 & 0.1946 & 118 & $\mathrm{~s}$ \\
\hline
\end{tabular}

This table shows that there is a significant correlation between high school students' ability to read and write. This can be justified by the $r$ value obtained $(0,4964)$ which exceeds the needed value (0.1946) to reject the null hypothesis (according to Hatch and Lazaraton, 1991). This enables us to conclude that there is a significant correlation between high school students' ability to read and write. Since the first hypothesis is rejected with confidence $P .05$, it is possible to measure how significant is this correlation. Applying variance overlap in this case, it can be concluded that there is $24.64 \%$ of correlation between high school learners reading and writing abilities as far as English is concerned.

The second research hypothesis is around the effect of level on the degree of correlation among high school EFL learners in their reading and writing abilities. As mentioned earlier, testing this hypothesis is done through comparing the degree of correlation between students' performance in the reading and writing tests across two levels: common core and first year baccalaureate students. Tables 3 and 4 show the results of these comparisons: Table 3 presents the correlation between reading and writing among common core students while table 4 is about correlation among first year baccalaureate students.

Table.3: Correlation between reading and writing among common core students

\begin{tabular}{|l|l|l|l|}
\hline $\begin{array}{l}\mathrm{R} \quad \text { value } \\
\text { obtained }\end{array}$ & $\begin{array}{l}\text { Critical value } \\
\text { needed }\end{array}$ & DF & P .05 \\
\hline 0,60 & 0.2500 & 58 & $\mathrm{~s}$ \\
\hline
\end{tabular}

The results shown in this table prove that there is significant correlation between the development of EFL learners reading and writing abilities at common core level. The strength of correlation reached $\mathbf{3 6 \%}$. This implies that $\mathbf{3 6 \%}$ of variance in the results of common students in the writing test can be accounted for by the development of students reading skills or vice versa as the two variables are totally independent. Concerning first year baccalaureate students, table 4 is used to present the results of the comparison.

Table.4: Correlation between reading and writing among both first year baccalaureate students

\begin{tabular}{|r|r|r|r|}
\hline $\begin{array}{r}\text { R value } \\
\text { obtained }\end{array}$ & $\begin{array}{r}\text { Critical } \\
\text { value } \\
\text { needed }\end{array}$ & DF & P .05 \\
\hline 0,83 & 0.2500 & 58 & $\mathrm{~s}$ \\
\hline
\end{tabular}

The $r$ value found - in this case 0,83 - really exceeds the critical value required - 0.2500 - to reject the null hypothesis. This means that the correlation between the two variables is significant. Another remark is related to 
the degree of overlap between first year baccalaureate EFL learners reading and writing skills. This can be proved by the variance overlap, which goes beyond $68 \%$ $(68.89 \%)$.

Based on the results of tables 3 and 4 , it can be easily noticed that the degree of correlation between high school students reading and writing abilities varies across levels (in this case across EFL common core and first year baccalaureate students). The findings of previous research on the relationship of reading and writing reviewed earlier supported by the results of this study indicate that reading and writing form important relations with each other.

\section{CONCLUSIONS, IMPLICATIONS, AND RECOMMENDATIONS}

This section discusses tow main points: the first point is related to conclusions of the study and the second one is about some implications and recommendations. As for the conclusions, they can be summarized in the following points:

$>$ There is a significant correlation between EFL high school learners in their performance in the reading and writing tests.

$>$ There is a significant correlation between the development of EFL high school learners' reading and writing abilities.

$>$ The significance of correlation between reading and writing skills development differs among high school students (in this study between common core and first year baccalaureate students).

$>$ There is a significant correlation between high school students' abilities to read and write and their level.

$>$ The degree of overlap between the learners' abilities to read and write $(24.64 \%)$ is still low although it is statistically significant enough to conclude that there is a correlation between the two variables. This point lead to question the extent to which integrating reading and writing instruction has been successful.

$>\quad$ The degree of overlap is greater among first year baccalaureate students.

$>$ The correlation between the development of EFL high school learners reading and writing abilities becomes stronger as students move from one level to another.

As for the implications, they are associated with the teaching, learning, and assessment of reading and writing. Students should be encouraged to relate the development of their reading and writing abilities. This implies that learners are required to use, for instance; their reading abilities while accomplishing a written task. In this regard, language teachers ought to encourage their learners to make use of and refer to their reading skills while writing and vice versa. Teachers, for instance, should use activities and assign tasks that encourage and require skills integration. Textbook designers need include activities and tasks (reading texts, reading comprehension tasks, witting tasks) that help teachers and learners refer to and develop these skills simultaneously. Such tasks may include, during post reading stage for instance, paraphrasing, commenting, or summarising. Doing such tasks requires learners to use the different writing skills developed during writing classes. Concerning assessment of these skills, teachers should prepare and design tests that call for the incorporation of both reading and writing for better performance and improvement.

Researchers are recommended to study in depth the relation between writing and reading. Teachers are also to be encouraged to do action research for better understanding of the correlation between these two main language skills. A deep and comprehensive understanding of the nature of correlation between reading and writing can help researchers come up with pertinent answers, practical suggestions, and more effective techniques for better learning and teaching of reading and writing. The findings of such studies can help researchers develop effective and suitable models that integrate both reading and writing instruction. Besides, language teaching and learning is ever dynamic. Information provided by applied linguists about the nature of language and the way it is learnt often leads to pedagogical shifts (Billy, 2010). The next section deals with some short comings related to this study.

\section{Limitations of the study}

Concerning the limitations, they are mainly related to the following points. It is highly expected that testing the relation between reading and writing in other languages such as Arabic and French would provide rich findings. Using a mixed approach (tests, questionnaires, and/ or interviews) to examine the correlation between reading and writing can only generate rich data upon which researchers can build more solid arguments for integrating the two skills. Considering these limitations in future studies will surely help researchers understand how these two skills relate to one another and how they interact.

\section{CONCLUSION}

This paper answers the question whether good readers are necessarily good writers. It does so through studying the correlation between students' reading and writing skills in English. The statistical test used in this paper enables us to decide on the significance of the relation between the 
variables under study. It has been concluded that there is a significant correlation between the development of EFL learners reading and writing skills. Another conclusion of this study is related to the development of these skills across levels. In this regard, it has been found the correlation between reading and writing becomes stronger as students move from one level (common core) to another (first year baccalaureate). Thus, teachers and learners ought to maintain and foster this correlation through creating more opportunities to integrate effectively these skills. This may help learners develop other necessary skills such as critical creative thinking abilities.

\section{ACKNOWLEDGEMENTS}

Special thanks to Dr. Taoufik Allah Afkinich, my academic supervisor, for his continuous support, encouragement; and guidance.

\section{REFERENCES}

[1] Al-Saadat, A. I. (2004). Investigating the Relationship of Reading and WritingAbilities in the English Language Program at King Faisal University. Scientific Journal of King Faisal University (Humanities and Management Sciences), 5 (1). 215-229

[2] Billy, O. S. (2010). Linking Reading and Writing in An English-As-A-Second-Language (ESL)

Classroom for National Reorientation and Reconstruction. International Education Studies Vol. 3, No. 3. 195-200.

[3] Cho, H. \& Brutt-Griffler, J. (2015) Integrated reading and Writing: A Case of KoreanEnglish Language Learners. Reading in a Foreign Language?Volume 27(2). 242- 261

[4] Flood, J. \&D. Lapp. 1987. Reading and Writing Relationships: Assumptions and directions. In J. Squire (Ed.). The dynamics of languagelearning. pp. 9-26.Urbana ILL: National Conference on Research in English.

[5] Hatch, E., \&Lazaraton, A. (1991). The Research Manual:Design and Statistics forApplied linguistics. USA. Heinle and Heinle Publishers.

[6] Hermida, J. (2009). The Importance of Teaching Academic Reading Skills in First-Year University Courses. The International Journal of Research and Review. Volume 3. September 2009.

[7] Ministry of National Education. (2007). English Language Guidelinesfor SecondarySchools: Common Core, first Year, and Second Year Baccalaureate.Curriculum Development Department. M.E.N.
[8] Olson, C. B., \& Land, R. (2007). A Cognitive Strategies Approach to Reading and Writing Instruction for English Language Learners in Secondary School.Research in The Teaching of English, 41. 269-303 